Portland State University

PDXScholar

Summer 8-30-2018

\title{
"My Teacher Says I'm an Overachiever, but I Think He's an Overexpecter" : Teacher Expectations, Self- Concept, and Academic Success
}

Jennifer Lea Campbell

Portland State University

Follow this and additional works at: https://pdxscholar.library.pdx.edu/open_access_etds

Part of the Communication Commons

Let us know how access to this document benefits you.

\section{Recommended Citation}

Campbell, Jennifer Lea, "'My Teacher Says I'm an Overachiever, but I Think He's an Overexpecter" : Teacher Expectations, Self-Concept, and Academic Success" (2018). Dissertations and Theses. Paper 4546.

https://doi.org/10.15760/etd.6431

This Thesis is brought to you for free and open access. It has been accepted for inclusion in Dissertations and Theses by an authorized administrator of PDXScholar. Please contact us if we can make this document more accessible: pdxscholar@pdx.edu. 
"My Teacher Says I'm an Overachiever, but I Think He's an Overexpecter" Teacher Expectations, Self-Concept, and Academic Success

by

Jennifer Lea Campbell

A thesis submitted in partial fulfillment of the requirements for the degree of

\author{
Master of Science \\ in \\ Communication
}

\author{
Thesis Committee: \\ Lauren Frank, Chair \\ Cynthia-Lou Coleman \\ Brian Manata
}

Portland State University

2018 


\begin{abstract}
This study explores the relationship between student judgments of teacher expectations and academic success, student self-concept and academic success, and student judgments of discrimination experiences and academic success. In the winter of 2018, a sample of 176 communication students at a northwestern university completed revised versions of the Teacher Treatment Inventory (TTI) and the Self-Description Questionnaire III (SDQ III), as well as the original Everyday Discrimination Scale (EDS). College-age students found the TTI confusing, and many participants said they did not have a relationship with their college professors. The hypothesis that suggested student judgments of teacher expectations would positively correlate with anticipated course grade was not supported, and no significant differences were found between male and female students' judgments of teacher expectations, as well as no significant differences among students of different races on judgments of teacher expectations. The hypothesis that student self-concept would positively correlate with anticipated course grades was partially supported. While some participants did judge themselves to have experienced forms of discrimination, those discriminatory experiences did not result in a significantly negative correlation with anticipated course grades. Implications for understanding expectancy effects and student self-concept as a pedagogical tool for increasing academic success are discussed.
\end{abstract}




\section{Dedication}

I dedicate this thesis to my fiancé, John Thomas Capell, for his infinite patience, endless support, and our shared love of knowledge and books. His willingness to proofread my papers regardless of where he was or the time of night, tactfully pointing out where I made arguments but did not back them up, helped make me a better writer. He has graciously taken a backseat to my life-long dream of an education, and I am forever grateful. Now that eight years of school are coming to an end, our lives together are truly beginning. I am very excited for our future and that he is there waiting for me to cross the finish line, cheering the loudest. I could not have asked for a better partner.

$\sim$ JTLC 


\section{Acknowledgements}

There are not enough words to express my gratitude to Dr. Lauren Frank for her commitment to me as a student, both as an undergraduate and as my thesis advisor.

Dr. Frank gave me countless hours of her time, was responsive to my emails and questions beyond any expectations, and offered me encouragement and support when I was confused or anxious. I knew as an undergraduate student that she was the perfect choice to mentor me through graduate school, and Dr. Frank has proven me correct. Dr. Frank should receive an award for her dedication and commitment to her students. I would also like to thank Dr. Cynthia-Lou Coleman and Dr. Brian Manata for their valuable insight and feedback. Their suggestions helped me craft a stronger thesis and also helped me understand my own study in much more depth. Each suggestion and subsequent revision contributed to a richer thesis. They have given me the gift of knowledge and understanding. Thank you.

I would also like to acknowledge the teachers I have encountered throughout this eight-year educational journey whose expectations and beliefs in me helped shape my own self-concept and contributed to my success when I initially believed I was too old and not smart enough to attend college. I am forever grateful that they saw in me what I did not see in myself. Often we are unaware of the influence we have on other people. I hope they know the literally life-changing impact they had on at least one student - me.

Finally, I want to thank my family who felt the loss of my presence at countless gatherings but never stopped encouraging me to achieve my dreams and continued to 
express their pride in me. While the tools they provided to help me succeed were valuable (e.g., pencils, a printer, a laptop), their love and support is what got me through. 
Table of Contents

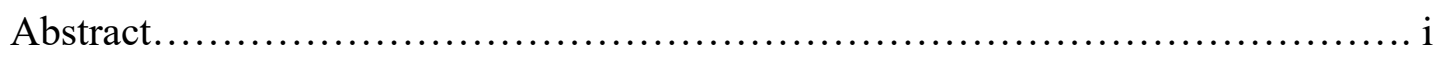

Dedication........................................................... ii

Acknowledgements................................................. iii

List of Tables............................................................ vi

\section{Chapter 1}

Introduction...............................................................

Chapter 2

Review of Literature.................................................... 4

Chapter 3

Methods..................................................................... 24

Chapter 4

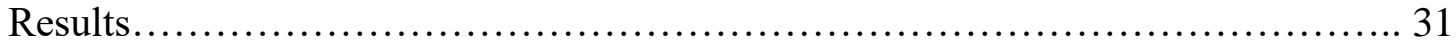

Chapter 5

Discussion.......................................................... 35

References............................................................... 43

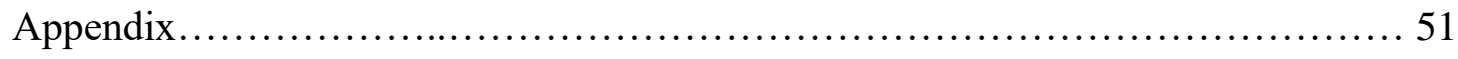


List of Tables

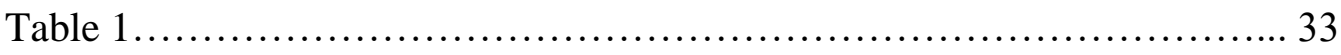

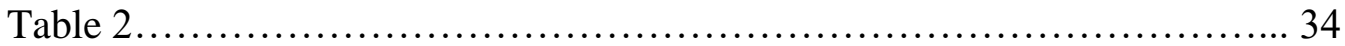


Chapter 1 - Introduction

The 1988 film Stand and Deliver is based on a real-life account of Jaime Escalante who taught mathematics to underprivileged children at Garfield High school in East Los Angeles (Mathews, 2010). In both the film and in real life, Escalante endeavored to increase mathematical academic success for the primarily Hispanic Garfield High students. In the movie, Escalante sets a goal of having all of his students taking advanced placement (AP) calculus by their senior year despite Escalante's colleagues who are cynical and feel the students are not capable. Despite society's cynicism, Escalante's positive expectations help the students meet their goal (Musca \& Menéndez, 1988).

In the film, the Educational Testing Service accused the students of cheating due to their high test scores. Escalante believed so strongly in his students that he challenged the testing service to allow the students to all retake the exam with only one day to prepare in concert with diligent monitoring by the Educational Testing Service during the exam. The climax of the film occurs when all of the students pass the exam a second time, with five students earning top scores (Musca \& Menéndez, 1988).

In the above example, Escalante's expectations of his students' abilities prompted changes in the students. The students began to believe they were capable of meeting their teacher's expectations, and the students' self-concept of their mathematical abilities shifted favorably resulting in a belief in their own abilities and ultimately academic success. Expectations can change behavior on the part of the recipient, and those behavioral changes can alter the trajectory of the recipient's life in positive and negative ways. For example, if a teacher tells a student that she is intelligent and capable of math, 
she may approach the topic with an open mind, seek tutoring if needed, and possibly even pursue a career that involves education in the sciences (e.g., doctor, scientist, engineer) a positive outcome. On the other hand, if that same teacher exhibits an expectation that females fare poorly in mathematics, she may never seek assistance if she struggles with math courses, assuming that women cannot do math, and she may never pursue a career that involves education in the sciences (e.g., doctor, scientist, engineer) - a negative outcome.

The purpose of the current study is to examine the impact of teacher expectations on adult learners and how those expectations affect academic success. If teachers have the ability, no matter how slight, to positively impact student success, this information is a valuable pedagogical tool. In addition, this study seeks to explore the relationship between students' self-concept and academic success, as well as students' judgments of discrimination and academic success.

Chapter two reviews literature that explores the relationship between teacher expectations, self-concept, gender stereotyping, and judgments of discrimination with academic success. Chapter three outlines the survey method used for the current study. The survey included three scales that assessed student judgments of their professors' expectations, student self-concept, and student judgments of everyday discrimination experiences. Chapter four is a description of the study results, which found positive relationships between self-concept and academic success but no relationship between gender and student judgments of teacher expectations or student judgments of discrimination and academic success. Chapter five discusses the study results and offers 
some thoughts related to outcomes, the study's limitations, and suggestions for future research. 
Chapter 2 - Review of Literature

Expectations that are specific to education consist of teachers' beliefs that their students will perform in a particular academic manner, many with outcomes measured through standardized testing or outcomes measured through laboratory experiments (Friedrich, Flunger, Nagengast, Jonkmann, \& Trautwein, 2015; Good, Aronson, \& Harder, 2007; Rosenthal \& Jacobson, 1968; Rubie-Davies, Peterson, Sibley, \& Rosenthal, 2015). Expectations also manifest in the form of parental beliefs and assumptions. For example, parents may structure a home environment that influences a child's academic achievement (Davis-Kean, 2005). Davis-Kean (2005) argues that the educational background and socioeconomic status of the parents ultimately affect their children's beliefs and behaviors toward academic success. As a result, it is important to note that academic outcomes are not solely related to teacher expectations but also the expectations students encounter in their environment.

An expectation is described as the judgment regarding the likelihood that some sort of future occurrence will happen (Cooper \& Hazelrigg, 1988; Haimerl \& Fries, 2010; Harris \& Rosenthal, 1985; Jussim \& Harber, 2005). This assumption of a future event prompts behavior in the expecter, where the expecter's beliefs are made known and become key components in the outcome (Cooper \& Hazelrigg, 1988; Haimerl \& Fries, 2010; Harris \& Rosenthal, 1985). In addition, the expression of expectations on the part of a teacher can impact the student's self-concept (Harris \& Rosenthal, 1985). For example, if a teacher expects that certain students have great academic potential and this belief is relayed to the students, the students may change their behavior by applying 
themselves more diligently to their studies, seek out tutoring and answers to their questions, and ultimately become more successful because of their teacher's expectations. For the purpose of this study, teacher expectations are defined as assumptions teachers have about their students' abilities and subsequent academic success. Teacher expectations manifest through behavior on the part of the teacher and are perceived and ultimately judged by the students (Agirdag, Van Avermaet, \& Van Houtte, 2013; Cooper \& Hazelrigg, 1988; Jussim \& Eccles, 1992; Rosenthal \& Jacobson, 1968). Behavior can include verbal and nonverbal communication on the part of the teacher and also materials provided such as syllabi that outline course requirements and beliefs about student conduct such as timeliness and respectful interactions. The students then interpret those expectations and form judgments about what is expected of them. Further, students who are of lower socioeconomic status or of minority status judge fewer (lower) success expectations from their teachers and fare more poorly than do students who are from a higher socioeconomic status or majority race such as white (Agirdag et al., 2013).

Very little literature exists that specifically defines the constructs perception and judgment. Garner, Hake, and Eriksen (1956) argue that perception is a relationship between a stimulus and a subsequent response. People frequently use heuristics (the rapid process of understanding something based on experience) to simplify complex cognitive problems and come to a conclusion or judgment (Tversky \& Kahneman, 1974). Funder and Colvin (1988) note the presumed purpose for making judgments of people's personalities is to predict subsequent behavior. For example, a student may see a teacher becoming impatient with another student who is habitually late to class (perception). The 
observing student may conclude the teacher's impatience to reflect an expectation of promptness (judgment).

Teacher expectations are important because they can impact students' academic success; research has supported the notion that when students judge high expectations from their teachers, the students shift their behavior to meet those expectations resulting in higher academic achievement (Friedrich et al., 2015; Jussim 1989; Jussim \& Eccles, 1992; Jussim \& Harber, 2005; Madon \& Jussim, 1997; Rosenthal \& Jacobson, 1968; Rubie-Davies et al., 2015; Sorhagen, 2013; Weinstein \& Middlestadt, 1979; Weinstein, Marshall, Brattesani, \& Middlestadt, 1982). This positive shift in behavior to meet teacher expectations is an example of the relationship between teacher expectations and academic success.

Academic success is measured in myriad ways to include standardized testing, laboratory experiments, and survey data (Agirdag et al., 2013; Friedrich et al., 2015; Rosenthal \& Jacobson, 1968; Rubie-Davies et al., 2015). These examinations look at trends in IQ tests, standardized tests that focus on general academic scores to include math and reading, and the student grades. This study will consider academic success to be each of the participating student's anticipated grade in their current communication course, where the grade will have either a positive or negative relationship with the construct being measured. The grade options presented to the students in this study range from A to F.

The difference between perception and judgment is nebulous, and the two terms tend to be used synonymously (Coleman, 1993; Firestone \& Scholl, 2015) but may 
simply be a matter of heuristics and affective thinking versus more emphasis on richer cognitive thinking (Firestone \& Scholl, 2015). The field of psychology argues that the difference comes down to seeing versus thinking (Firestone \& Scholl, 2015). For example, a person may see an object in a passenger-side car mirror and perceive it as being closer than the object really is versus cognitively judging the object to be at a more realistic distance (Firestone \& Scholl, 2015). Firestone and Scholl (2015) argue that seeing (perceiving) leads to thinking (forming judgments). In other words, perception is the way in which something is sensed and interpreted, and judgment is the formation of a conclusion.

For the purpose of this study, the term perception will be used to indicate interpretations on the part of students from a level of heuristics when trying to assess their teachers' expectations. The term judgment will be used to indicate a conclusion based on perceptions of teacher expectations.

Attribution theory helps explain the mechanisms at work with regard to expectations, wherein behavioral changes in an individual are motivated by the judgments and expectations of others (Jones \& Nisbett, 1972). Attribution theory examines the relationship between two people and behavior changes that result, specifically as a way to explain success or failure (Jaspars, Fincham, \& Hewstone, 1983). Individuals may respond in different manners, where some receivers of expectancies may attribute their successes or failures to other people, while some receivers of expectancies may attribute their successes or failures to their own effort (Jones \& Nisbett, 1972). Some people engage in self-serving bias, where they tend to "believe positive 
experiences are due to internal attributions and negative experiences are due to external attributions" (Robinson, 2017, p. 209). For example, a student who is doing poorly in school may attribute his struggles to unreasonable teacher expectations (external event), and a student who is performing well in school may attribute his success to his dedication (internal event); however, the teacher may disagree with both and attribute the student's academic results to other causes (Jones \& Nisbett, 1972). According to Jones and Nisbett (1972), there is a "pervasive tendency for actors to attribute their actions to situational requirements whereas observers tend to attribute the same actions to stable personal dispositions" (p. 80). For example, the teacher (observer) of the same person who is doing poorly (actor) may feel that the struggling student is merely a low achiever and that the successful student's results are due to the teacher's high expectations for ability and subsequent academic success.

Studies examining teachers' expectations have shown those expectations may affect grade school children's academic success (Agirdag et al., 2013; Harris \& Rosenthal, 1985; Jussim, Harber, \& Crawford, 2005; Jussim \& Harber, 2005; Jussim \& Eccles, 1992; Jussim, 1989; Karcher, Davidson, Rhodes, \& Herrera, 2010; Madon \& Jussim, 1997; Rubie-Davis et al., 2015; Rosenthal \& Jacobson, 1968; Sorhagen, 2013; Spencer, Steele, \& Quinn, 1999; Weinstein \& Middlestadt, 1979; Weinstein et al., 1982) and are frequently referred to using the term Pygmalion (Friedrich et al., 2015; Haimerl \& Fries, 2010; Rosenthal \& Jacobson, 1968). The Pygmalion effect credits students' success to the students' judgments of high expectations from their teachers (Friedrich et al., 2015; Rosenthal \& Jacobson, 1968) as well as attributing student success to the 
attention received by teachers who had high expectations for those students (Gurland \& Evangelista, 2014; Haimerl \& Fries, 2010; Karcher et al., 2010; Rosenthal \& Jacobson, 1968).

Rosenthal and Jacobson's (1968) classic study revealed that teachers who believed students to be academically gifted unintentionally gave those students cues demonstrating their expectations; as a result, the targeted children did excel academically. In addition, students form expectancies of their teachers, which also produce an effect that is consistent with the students' beliefs (Gurland \& Evangelista, 2014). For example, a student may judge that his teacher is an unreasonably hard grader; therefore, the student may form low expectations of his grade outcome and not put forth enough effort, which results in an associated expectancy effect. Further, students' expectancies of their teachers are associated with the nature of the student-teacher interpersonal relationship, where students shift their behavior to ways that fulfill those expectations (Gurland \& Evangelista, 2014; Karcher et al., 2010).

Weiner, Frieze, Kukla, Reed, Rest, and Rosenbaum (1972) address Rosenthal and Jacobson's (1968) Pygmalion study through the theoretical framework of attribution theory. The authors reiterate Rosenthal and Jacobson's (1968) false assertions to teachers that the teachers had some students in their classrooms with exceptional academic potential. Those false expectations prompted the teachers to shift their behavior, paying more attention to the so-called gifted students (Rosenthal \& Jacobson, 1968; Weiner et al., 1972). Subsequent IQ testing revealed the alleged gifted students to have achieved intellectual gains (Rosenthal \& Jacobson, 1968; Weiner et al., 1972). 
Weiner and colleagues (1972) argue that the teachers' expectations certainly led the teachers to believe that some of their students had exceptional academic ability, and these expectations subsequently prompted the teachers to behave in a different manner. While Harris and Rosenthal (1985) performed a meta-analysis that revealed 31 different behaviors exhibited by teachers toward their high-expectancy students (e.g., smiles, encouragement, eye contact), Weiner and colleagues (1972) argue that the specific behavioral changes on the part of the teachers in the Rosenthal and Jacobson (1968) study that created a rise in their students' intelligence scores is unknown but that attribution theory can offer clues to the teachers' behavior.

In addition to attributing intellectual increases on the part of academically successful students to a gifted ability, Weiner and colleagues (1972) assert that since the teachers held expectations of high achievement for the selected students, it is unlikely that the intermittent failures that the high-achieving students likely experienced would have been attributed by the teachers to lack of ability on the part of the students. Specifically, some of the students they expected to succeed would likely have encountered contradictory results, necessitating an explanation in the teachers' minds. Weiner and colleagues (1972) opine that any failure displayed by the students would likely be attributed to a lack of sufficient effort on the part of those students. In other words, one of the characteristics of attribution theory is that failure would be attributed to lack of effort rather than a lack of ability (Weiner et al., 1972). Further, the teachers might be communicating causes for failure to the students that could prompt the students to try harder resulting in higher student achievement. For example, a teacher could tell 
her underperforming students that they are not spending enough time studying, which could prompt them to study longer. Weiner and colleagues (1972) state, “...false ability expectancies have implications for teacher attributions concerning the causes of success and failure, and these attributions may have motivational consequences" (p. 118). As far as the low-expectation students, attribution theory would suggest that the teachers likely attribute the low-achieving students' failures to the students' internal sources such as lack of ability or effort rather than an external cause such as the teacher's time and attention (Jones \& Nisbett, 1972).

For the purpose of the current study, the terms teacher or professor will designate someone who teaches in a university setting, and students will be defined as people who are studying in a college environment. Further, references to self will be from the perspective of students, and expectations will be those of the university teachers or professors.

The opposite of Pygmalion (a positive expectancy effect) is the Golem effect (Eden, 1990). The Golem effect happens when a teacher has low expectations toward students and, much like Pygmalion, behaves in a manner reflective of those expectations but resulting in a negative expectancy effect and poor academic outcomes. In addition, studies have revealed students who experienced low expectations from their teachers had significantly worse outcomes when compared to the level of increased outcomes experienced by the high-expectation students (Eden, 1990) and occur more commonly than Pygmalion (Brophy, 1983). While the Golem effect is as crucial to understand as 
Pygmalion because of its potential hazardous consequences, this study will focus on Pygmalion and positive expectancy effects.

Naturalistic studies (direct observation in a natural setting) have consistently supported the notion of expectancy effects, where teachers developed false expectations toward children, and those expectations were delivered (Fischbach, Baudson, Preckel, Martin, \& Brunner, 2013; Jussim et al., 2005; Madon \& Jussim, 1997; Jussim \& Eccles, 1995; Rosenthal \& Jacobson, 1968; Rubie-Davies et al., 2015; Sorhagen, 2013). Regardless of the setting, arguments have been made that expectancy effects are a real phenomenon but modest in significance (Agirdag et al., 2013; Fischbach et al., 2013; Friedrich et al., 2015; Jussim, 1989; Jussim et al., 2005; Jussim \& Harber, 2005; Sorhagen, 2013) with small effect sizes (Agirdag et al., 2013; Cooper \& Hazelrigg, 1988) and more likely to be due to accurate teacher judgments of student ability than a form of expectancy effect (Brophy, 1983; Fischbach et al., 2013; Jussim, 1989; Jussim \& Eccles, 1995; Jussim et al., 2005; Jussim \& Harber, 2005; Madon \& Jussim, 1997). However, a meta-analysis performed by Rosenthal and Rubin (1978) that examined 345 studies on expectancy effects found statistical significance for more than a third of the studies, which is too large a number to dismiss and not a matter of chance (Kierein \& Gold, 2000). Nevertheless, the fact that approximately two-thirds of the studies failed to find statistical significance cannot be ignored (Kierein \& Gold, 2000).

In summary, the literature reveals that teachers hold expectations for their students and express those expectations either explicitly through syllabi or verbal instructions, or they express the expectations through nonverbal behavior (Agirdag et al., 
2013; Rosenthal \& Jacobson, 1968; Jussim \& Eccles, 1992). The students perceive these expectations and then form judgments regarding what is expected of them (Rosenthal \& Jacobson, 1968; Jussim \& Eccles, 1992). These judgments in turn may impact the students through Pygmalion or Golem effects reflective in the students' academic success (Eden, 1990). The literature on teacher expectations and academic outcomes prompts the following hypothesis:

H1: Students' judgments of their teachers' expectations will positively correlate with students' expected grades in the class.

Steven Chaffee (1991) cites the importance of thoroughly explicating constructs within scholarly research to avoid murky and conflicting definitions. Chaffee (1991) argues that the field of communication research is grounded in discourse and frequently represented quantitatively; however, quantifiable research is of little use unless the constructs under investigation can be thoroughly organized, their meanings explained, and their scales justified. Self-concept is shown to have a strong positive relationship with academic outcomes. The importance of this construct necessitates a clear understanding of the term.

Research examines the relationship between expectancy effects and self-concept, where one's abilities are impacted by one's negative or positive self-concept (Friedrich et al., 2015; Jussim, 1989; Jussim \& Eccles, 1995; Karcher et al., 2010; Madon \& Jussim, 1997; Marsh \& Martin, 2011; Pipitone \& Welch-Cline, 1989; Weinstein \& Middlestadt, 1979). Beliefs about one's self-concept and one's abilities set the stage for potential success, and people with a low self-concept are particularly susceptible (Madon \& 
Jussim, 1997). Self-concept is based on experiences and one's environment (Bong \& Skaalvik, 2001; Huang, 2011; Wylie, 1974), and self-concept can be reinforced through reflected appraisals from other people (Bong \& Skaalvik, 2003).

Self-esteem and self-concept are terms which are used interchangeably and frequently confused within academic literature leading to myriad operational definitions (Huang, 2011; Marsh \& Martin, 2011; Wylie, 1974). Scholars agree that there is much confusion regarding self-constructs but that self-esteem differs from self-concept primarily due to its evaluative nature (Huang, 2011; Pipitone \& Welch-Cline, 1989; Zeigler-Hill, 2013). For example, a student with a high self-concept may believe that he is capable of writing an essay for a communication class and receiving an A, because his prior experience with writing essays for communication classes resulted in an A grade. A student experiencing high self-esteem may believe that he is a gifted writer because of prior experiences writing essays for communication courses that resulted in an A grade. Self-esteem was a term originally coined by William James in the 1800 s to describe the positive way in which people view themselves when they have achieved important goals (Zeigler-Hill, 2013). This original definition remains stable to the extent that self-esteem is now considered to be an "evaluative" process, where people determine how much they like themselves and assess their abilities (Zeigler-Hill, 2013, p. 2). Selfesteem relates to value judgments that reflect what people believe about themselves and their self-worth, either negative or positive (Pipitone \& Welch-Cline, 1989; Zeigler-Hill, 2013). For example, a self-esteem judgment could be "At times I think I am no good at all," or "I feel I have a number of good qualities" (Rosenberg, 1965, p. 17). People with 
a high self-esteem express positive evaluations of themselves, and people with low selfesteem express negative evaluations of themselves (Pipitone \& Welch-Cline, 1989; Zeigler-Hill, 2013). In other words, self-esteem is more value-based and an impression one holds about one's worth, and self-concept is a construct about one's abilities based on judgments of others and life experience. Ditzfeld and Showers (2013) acknowledge the intersection between self-esteem and self-concept, where variations in the components of self-concept can create changes in one's self-esteem.

In addition, confusion also exists between self-concept and self-efficacy (Bong \& Skaalvik, 2003; Huang, 2011). Self-concept and self-efficacy are similar because they both address judgments of competence (Hughes, Galbraith, \& White, 2011). While similar to self-concept, self-efficacy focuses more on tasks, context, and situations (Huang, 2011) with a cognitive emphasis regarding beliefs of one's abilities (Hughes et al., 2011). Where self-concept can be specific to one's environment with an affective emphasis regarding beliefs of one's abilities, self-efficacy is assessed based on tasks that are temporal and can be measured (Huang, 2011; Hughes et al., 2011). For example, a student with a high self-concept may believe that he is capable of getting an $\mathrm{A}$ in a communication course, because his prior experience with communication courses at the same university have resulted in the same grade. A student experiencing a sense of selfefficacy in the same course may believe he possess the skills to complete an assigned essay within the designated timeframe (a measured task). While the two constructs are similar, self-concept evaluates based on a belief in one's level of skills and abilities, where self-efficacy simply evaluates whether or not a task can be accomplished based on 
the existence of skills and abilities (Bong \& Skaalvik, 2003). Hughes and colleagues (2011) argue that people who are utilizing self-efficacy beliefs are asking themselves if they "can" do something such as "Can I do mathematics," where beliefs regarding one's abilities utilizing self-concept ask "being" questions such as "Am I good at mathematics" (p. 278). Although the distinctions between self-concept and self-efficacy can be articulated, Hughes and colleagues (2011) point out that there are very few studies examining the distinct differences between the two constructs, and the studies that do exist are inconclusive.

Ruth Wylie (1974) also references the work of American psychologist William Marsh during the late 1800s and his interest in the self, which contributed to the field of psychology. Wylie (1974) notes until the mid-1900s, psychologists who focused on behavior essentially dismissed self-concept as "anathema" to their field (p. 2). As Freudian theorists began placing more emphasis on the self around the 1960s, theories that emphasized the self began to flourish (Wylie, 1974). According to Wylie (1974), this was when American psychologists were struggling with their own behavioristic models as a means to explain their observations and began to pay more attention to notions involving psychoanalysis.

Wylie (1974) categorizes two types of self-concept theorists: the first is the phenomenological theorist, someone who believes that human behavior cannot be understood or predicted without taking into consideration a person's awareness of their environment and their experiences and how their judgments of these experiences play a role in shaping the self-concept. In other words, there is a relationship between the self 
and one's environment. The second type of theorist is the non-phenomenological theorist, someone who believes a person's knowledge, judgments, and motivations exist without awareness resulting in a self-concept that is formed unconsciously (Wylie, 1974). The differing approaches to studying self-concept have contributed to its nebulous definition.

Due to the inferential nature of self-concept, appropriate measurement of the construct has been problematic (Huang, 2011; Wylie, 1974). Wylie (1974) argues that this conflict can be primarily traced to whether or not a researcher wishes to be identified as phenomenological. Whether or not a researcher identifies their approach as phenomenological is not the only issue. Much like other fields, psychologists studying self-concept have failed to examine other forms of measurement and analyses leading to multiple measures that were used once or twice resulting in issues with construct validity (Wylie, 1974). For the purpose of this study, facets of self-concept will be examined from a phenomenological perspective, where a person's experiences and environment contribute to their beliefs about their abilities relating to academics, emotional stability, honesty/reliability, and general self-concept.

Bong and Skaalvik (2003) identify five key precursors that influence self-concept. The first precursor is frames of reference, where people judge themselves based on their surroundings and frequently engage in social comparison. Bong and Skaalvik (2003) also note that frames of reference are the most crucial in the development of one's academic self-concept. The second precursor is causal attributions, where people attribute their successes or failures to elements of their self-concept. Bong and Skaalvik 
(2003) argue that there is a reciprocal relationship between self-concept and attributions, where the types of causal attributions assigned to prior successes or failures impact selfconcept and the resulting self-concept from the prior experiences then influences future attributions. The argument of causal attributions and their relationship to self-concept links directly back this study's use of attribution theory. If a student gets good grades in a class, he is likely to attribute that success to his abilities and his prior positive academic outcomes (Robinson, 2017). However, if a student gets a poor grade in a class, he is likely to attribute that grade to prior experience and a negative environment (Robinson, 2017). For example, the student may argue that everyone knows the research methods teacher is the hardest one on campus, or the student may argue that he has never been good at science-based courses and does not possess that skill. The third precursor is reflected appraisal, where people take on beliefs about themselves based on how they think others view them. Reflected appraisal is considered to be the most dominant source of information about one's self. The fourth precursor is mastery experiences, which are schema based on a person's prior experiences. The fifth precursor is psychological centrality, which is the notion that levels of self-concept are affected by the psychological degree of importance of a self-concept trait (Bong \& Skaalvik, 2011).

Jussim (1989) found that students who judged their teachers to have high expectations regarding the students' academic abilities resulted in an increase in the students" "self-concept of ability" (p. 476). Those students may have gone through the five frames of reference and felt a high level of psychological centrality regarding their academic abilities. In addition, a meta-analysis of longitudinal studies that examined the 
relationship between self-concept and academic success revealed "positive effects of selfconcept on academic achievement and of academic achievement on self-concept" (Huang, 2011, p. 524). The literature on self-concept prompts the following hypothesis:

H2: Student scores on the self-concept scales will positively correlate with students' expected grades in the class.

Ample literature exists on the relationship between gender stereotypes of females and their subsequent academic success (Bonnot \& Croizet, 2006; Good et al., 2007; Kiefer \& Sekaquaptewa, 2007; Spencer et al., 1999; Steele \& Ambady, 2005) and the relationship between gender stereotypes of females and their self-concept or self-esteem (Chatard, Guimond, \& Selimbegovic, 2006; Pipitone \& Welch-Cline, 1989) with a heavy emphasis on mathematical self-concept and academic success. However, little research examines teacher expectancy effects and gender (Jussim et al., 2005; Jussim \& Eccles, 1992). In experimental settings when a test-taking environment was manipulated to reflect a masculine tone versus a neutral tone, females performed more poorly in the masculine setting and excelled in the neutral setting (Good et al., 2007). Once the environment was changed to remove stereotypical influences, the women were able to achieve greater academic success than the males (Good et al., 2007). In addition, females were noted to perform more poorly on a math exam when the number of males in the room was increased (Good et al., 2007). Pipitone and Welch-Cline (1989) examine expectancy effects through the lens of gender and self-esteem. While the current study is emphasizing self-concept, self-esteem is still important due to its intersection with selfconcept and impact on students' critical self-evaluations. Pipitone and Welch-Cline 
(1989) suggest that females internalize inferior "social definitions of their worth" (p. 16), which could influence their self-esteem and ultimately their performance.

Jussim and Eccles (1992) argue that the sex of students can impact teacher judgments and prompt different treatment. McKown and Weinstein (2002) studied grade school children and discovered low expectations on the part of the teachers for females' mathematic abilities, as well as both male and female African American students. Both groups of students demonstrated a statistically significant relationship between negative teacher expectancies and negative academic outcomes (McKown \& Weinstein, 2002).

While much of the literature on gender and academic outcomes focuses on the math domain, this study seeks to examine whether or not there is a general relationship between teacher expectations and gender. The literature on teacher expectations and gender prompts the following research question:

RQ1: Is there a significant difference between female students' and male students' judgments of teacher expectations?

When people experience discrimination, the experience results in feelings of being devalued (Baysu, Celeste, Brown, Verschueren, \& Phalet, 2016; Eccles, Wong, \& Peck, 2006). These experiences result in a state of anticipatory anxiety, where recipients of discrimination are prepared for future discriminatory experiences (Baysu et al., 2016). In longitudinal studies, experiences of discrimination and low expectations hindered academic success (Alfaro, Umaña-Taylor, Gonzales-Backen, Bámaca, \& Zeiders, 2009; Baysu et al., 2016; Eccles et al., 2006; McKown \& Weinstein, 2002; Thompson \& Gregory, 2011). In addition, Eccles and colleagues (2006) report that when African 
American college students experience discrimination in academic institutions that have a predominantly white student population, they experience a significant impact on their ability to adjust to the college environment and a significant impact on their mental health. Further, Thompson and Gregory (2011) note that as children grow up and become more aware of their racial identity, they also become more skilled cognitively to judge how their racial group is being treated by society, which would include academic institutions.

Literature on the topic reports discrimination as both overt and covert to include racial slurs, racial bias related to discipline decisions, and general beliefs of being treated unfairly based on one's race (Thompson \& Gregory, 2011). Discrimination is less often denoted and more commonly connoted on the basis of racial identity, where students experience being treated in an unfair manner compared to their peers (Alfaro et al., 2009; Baysu et al., 2016; Eccles et al., 2006; McKown \& Weinstein, 2002). While heuristics may connote discrimination to be related to one's racial group identity, for the purpose of this study, discrimination is open to interpretation on the part of the student. This study is more interested in whether or not feelings of discrimination impact a student's ability to maintain their course grades than the type of discrimination felt. Therefore, discrimination includes, but is not limited to, discrimination experiences based on race, gender, physical ability, sexuality, religion, body size, age, and appearance. Also for the purpose of this study, race will be considered a categorical group identity that students may self-select such as White, African American, or Native American. 
Importantly, research has also shown perceptual biases on the part of teachers when it comes to marginalized social groups such as older students, new students, students of color, and students who are low achievers (Jussim, 1989; Jussim \& Eccles, 1992; Jussim \& Eccles, 1995; Jussim \& Harber, 2005; Madon \& Jussim 1997; McKown \& Weinstein, 2002; Sorhagen, 2013; Weinstein \& Middlestadt, 1979; Weinstein et al., 1982). Studies have revealed stronger statistical support for the concept of expectancy effects when focusing on low-achieving students (Jussim, 1989; Jussim \& Eccles, 1995; Madon \& Jussim, 1997), and disadvantaged students (e.g., students of color, older students, new students) who experienced higher rates of expectancy effects (Agirdag et al., 2013; Jussim \& Harber, 2005; Madon \& Jussim, 1997; Sorhagen, 2013). Agirdag and colleagues (2013) note, "more favorable teacher expectations are found for ethnic majority and higher SES pupils even after controlling for actual levels of academic achievement" (p. 6) and that teachers feel they have less of an ability to teach "nonnative and working class pupils and that these teachability expectations have an indirect impact on pupils' achievement through pupils' feelings of academic futility” (p. 2). Further, people are most sensitive to the effects of expectations when they are in new situations or when they are feeling vulnerable in unfamiliar circumstances (Jussim \& Harber, 2005). The literature on discrimination and academic outcomes, as well as expectancies and marginalized groups prompts the following hypothesis and research question:

H3: Students who score higher on the Everyday Discrimination Scale will be less likely to expect a high grade in the class. 
RQ2: Is there a significant relationship between students' race and their judgment of teacher expectations?

Jussim and Eccles (1995) argue that expectancies have greater potential when people are experiencing a major transition in life, when they are in new situations, or when they are questioning their own self-concept and abilities. They further assert that expectancy effects "may contribute fundamentally to the development and change of social and personality attributes from the cradle to the grave" (Jussim \& Eccles, 1995, p. 75). These profound assertions regarding the relationship between expectations, selfconcept, and academic outcomes have prompted this study. 


\section{Chapter 3 - Methods}

The following chapter will show that scales have been created for the variables in this study to include judgments of teacher expectations, self-concept, and judgments of discrimination experiences. These scales have been aggregated to reflect the average response for each question. Reliability measures will be provided for each aggregated variable.

\section{Participants}

During the winter term of 2018, undergraduate students in communication classes at a midsized public university in the Pacific Northwest were solicited for a survey (see Appendix) that examined the relationships among self-concept, judgments of teacher expectations, and expected course grade. Of the six communication classes in this study, one was introductory, and five were upper-division classes. The survey was taken online via Qualtrics outside of normal class time, and extra credit for participation was offered. Students who declined to participate in the survey were offered an alternate extra credit option. After Institutional Review Board (IRB) approval and subsequent informed consent obtained on the part of participants (see Appendix), participants were able to proceed to the survey. Risks associated with the survey were minimal, as respondents may have felt uncomfortable when asked to share information about their judgments of discrimination.

A total of 176 students began the survey, and 162 students completed the survey in its entirety. Of the respondents, $96(55 \%)$ were female, and 60 (34\%) were male. Age ranged from 18 to 48 years $(M o=22, M d n=23)$. The large portion $(n=91,52 \%)$ of the 
sample listed their race/ethnicity as white, but other races and ethnicities were represented as well. African American students made up 6\% $(n=11)$ of the sample, and Latino/Hispanic students made up $9 \%(n=16)$ of the sample. The rest of the minority students $(n=40,23 \%)$ listed their race/ethnicity as Native American, Asian, Pacific Islander, or other.

\section{Measures}

Teacher expectations. The Teacher Treatment Inventory (TTI) is a scale that was originally used in four experimental conditions to "measure students' perceptions of the frequency of 44 teacher behaviors toward a hypothetical male or female high or low achieving student" (Weinstein et al., 1982, p. 681). The scale was originally designed by Weinstein and Middlestadt (1979) and given to first-grade through sixth-grade students. The current study adjusted the questions to target individual judgments rather than the participants' observations of their professors interacting with other students, changed terminology to be more reflective of a college environment, focused on questions relating to expectations, improved face validity and construct validity, and also increased scale reliability. These changes reduced the scale from 44 questions to 20 questions.

The current study edited questions to replace the word teacher with the word professor and also edited questions to reflect a direct address rather than asking about a hypothetical other student. For example, instead of asking "The teacher makes John (Anne) feel he (she) did very well when he (she) finishes reading or gives the right answer" (Weinstein et al., 1982, p. 684), the question was edited to ask "The professor makes me feel I did very well when I give the right answer." 
The current study also focused on questions that emphasized teacher expectations and questions that could be applied to a college environment. Questions that were judged to reflect high teacher expectations were kept, and questions that assessed how work was being done in the classroom were omitted. For example, the question "John (Anne) is tested on things that he (she) has learned in class" (Weinstein et al., 1982, p. 685) is more reflective of the teacher's skillset rather than assessing the students' judgments of the teacher's expectations, and the question "The teacher watches John (Anne) closely when he (she) is working" (Weinstein et al., 1982, p. 684) is more appropriate for an elementary classroom than for a college classroom. Further, questions that were unclear as to whether or not a higher number on the scale would indicate more positive expectations were removed (e.g., the professor calls on me when my hand is up).

The final editing process improved face validity and construct validity. In addition, the edited scale went from a Cronbach $\alpha$ coefficient that ranged from 0.71 to 0.80 based on the respective subscale to a Cronbach $\alpha$ coefficient of 0.81 for the current study, which gave the scale for this study greater reliability than the scale in the original study.

The TTI ultimately translates into judgments formed on the part of the individual student. Student judgments reveal what the students believe their teachers expect of them and of their academic abilities. The scale asks students questions about their professors that require the students to stop and ponder their professors' behavior in the classroom toward them specifically as individual students. The process of thinking about their professors' behavior will theoretically come from a more cognitive level and result in a 
judgment of their professors' expectations. For the current study, the scale was used in an attempt to measure student judgments of their teachers' behaviors and expectations of them as students while considering the professor in their current communication class. Specific survey questions included, "The professor is excited when working with me," and "The professor scolds me for not listening" (Weinstein et al., 1982, pp. 684-685). For the complete scale, see the Appendix. Respondents rated each of the 20 items on a 5-point Likert-type scale that ranged from $1=$ never to $5=$ always. Each individual's scores were averaged into a single variable. The Cronbach $\alpha$ coefficient for the edited TTI was 0.81

Self-concept scale. The Self-Description Questionnaire III (SDQ III) was created for a late adolescent population to include college-age students and "designed to measure 13 factors of self-concept" (Marsh \& O'Neill, 1984, p. 153). This is a 136-item scale that was re-designed to accommodate late adolescents, which would be a more "valuable tool for the study of university students" (Marsh \& O’Neill, 1984, p. 155). For the purpose of this study, the scale was pared down to 27 items in validated subscales that focus on academic and general self-concept traits. Subscales that pertained to physical abilities/sports, problem solving/creativity, physical appearance, same-sex relationships, opposite-sex relationships, parent relationships, and religion/spirituality were considered extraneous and outside the scope of this study's focus on academic achievement (see Appendix). Specific survey questions included "I find that mathematics is one of my best subjects," "Overall, I have a lot to be proud of," and "I learn things quickly in most subjects” (Marsh \& O’Neill, 1984, p. 170). 
The self-concept scale used in this study utilizes questions that probe into students' beliefs about their abilities based on their prior experience, their environment, and questions of being. The scale has internal validity due to its focus on phenomenological self-concept rather than self-esteem or self-efficacy. Respondents rated each of the 27 items on a 5-point Likert-type scale that ranged from $1=$ strongly disagree to $5=$ strongly agree. Positive and negative items were intentionally alternating to encourage respondent engagement with the questions. Each individual's scores were averaged into a single variable to measure the mean of all scale points. The Cronbach $\alpha$ coefficient for the items included from SDQ III was 0.85 .

Following original validation of both the overall SDQ III and its component subscales, subscales were also computed to examine self-concept as it relates to mathematics, verbal/communication skills, honesty/reliability, emotions, general selfconcept, and general academic skills. The Cronbach $\alpha$ coefficient for the mathematics subscale was .91 , the verbal/communication subscale was .82 , the honesty/reliability subscale was .76, the emotional self-concept subscale was .78, the general self-concept subscale was .81 , and the general academic skills subscale was the lowest at .68 .

Judgments of discrimination. The Everyday Discrimination Scale (EDS) is a scale designed to measure "more chronic, routine, and relatively minor experiences of unfair treatment" (Williams, Jackson, \& Anderson, 1997, p. 340). This is a 9-item scale that attempts to capture experiences in the lives of participants (see Appendix). This scale is appropriate for the current study because it offers agency to the participants to determine discrimination for themselves rather than categorical designations that may be 
limiting. Specific survey questions include asking students if "You are treated with less courtesy than other people are," "People act as if they think you are not as smart," and "People act as if they think you are dishonest" (Williams et al., 1997, p. 340). Respondents rated each of the 9 items on a 5-point Likert-type scale that ranged from $1=$ very untrue of me to $5=$ very true of me. The EDS was aggregated into a single variable to measure the mean of all scale points. The Cronbach $\alpha$ coefficient for the EDS was 0.92 .

Students' academic success. The survey also asked participants to volunteer the grade they expected to receive for the class, as the signifier for academic success in this study is expected course grade.

Additional measures. In addition, demographic information that included sex, age, and racial identification was requested to support the research questions that explored a relationship between student judgments of teacher expectations and gender, as well as with race.

\section{Analysis}

H1 explored a relationship between judgments of teacher expectations and the associated students' academic success. H2 explored a relationship between student selfconcept and the students' academic success. H3 explored a relationship between student judgments of discrimination and the students' academic success. These hypotheses were tested using Spearman's rho correlation because variables were not distributed normally. RQ1 explored a difference between male and female student judgments of teacher expectations. This research question was tested using an independent samples $t$-test. 
RQ2 explored a relationship between student race and those students' judgments of teacher expectations. This research question was tested using ANOVA. Some of the scales varied in the number of respondents. All scales were analyzed based on the number of participants who answered the scales for that hypothesis or research question. An alpha of .05 was set a priori for statistical significance. 
Chapter $4-$ Results

This study measured student judgments of their professors' expectations, a measure of self-concept, individual self-concept subscales categorized by topic, and student judgments of discrimination experiences. Descriptive statistics for the variables in this study are shown in Table 1, as well as a correlation table reflected in Table 2.

H1 suggested there would be a positive relationship between student judgments of teacher expectations and academic success. Analysis using Spearman's rho testing was selected, as the scale for student grades was ordinal. There was no statistically significant correlation in the data set between judgments of teacher expectations and the students' anticipated course grades (Spearman $\left.r_{s}(160)=0.12, n=162, p=.14\right)$. H1 was not supported.

Students reported the areas of their self-concept that they most favorably assessed were honesty and reliability, followed closely by their general self-concept outlook, and then verbal and communication skills. All three of these self-concept constructs ranked nearly the same. Students reported mathematical skills as the lowest aspect of their selfconcept. Student judgments of discrimination experiences ranked the lowest of all scale means. Participants were also asked to share the grade that they anticipated receiving in their current communication course $(M=9.8, S D=2.0)$. The results represent grades on a scale from $\mathrm{A}$ to $\mathrm{F}$, where $\mathrm{A}$ is 12 and $\mathrm{B}+$ is 10 ; therefore, the average anticipated grade was approximately $\mathrm{B}+$.

Self-concept was measured by examining individual self-concept facets to include mathematics, communication/verbal skills, honesty/reliability, emotions, general self- 
concept, and general academic skills. All of these subtopics were also aggregated into one scale and tested. $\mathrm{H} 2$ suggested there would be a positive relationship between levels of self-concept and expected grade in the class. Aggregated levels of self-concept were significantly correlated with the students' anticipated course grades (Spearman $r_{s}(157)=$ $0.35, n=159, p<.001)$, as well as the general self-concept subscale (Spearman $r_{s}(157)=$ 0.27, $n=159, p=.001$ ). Neither subscale that focused on mathematics (Spearman $\left.r_{s}(157)=0.15, n=159, p=.07\right)$, nor emotions $\left(\operatorname{Spearman} r_{s}(157)=0.04, n=159, p=\right.$ .64) achieved a statistically significant correlation with the students' anticipated course grades. However, both communication/verbal skills (Spearman $r_{s}(157)=0.39, n=159$, $p=<.001)$ and general academic skills $\left(\right.$ Spearman $\left.r_{s}(157)=0.36, n=159, p<.001\right)$ were statistically significantly related to anticipated course grades with similar magnitudes. While of a lesser magnitude, support was also found for a statistically positive correlation between honesty/reliability and anticipated course grade $\left(\operatorname{Spearman} r_{s}(157)=0.16, n=159, p=.04\right) . \mathrm{H} 2$ was partially supported with the aggregated self-concept scale and the subscales of general self-concept, communication/verbal skills, general academic skills, and honesty/reliability reflecting statistical significance for a relationship with students' anticipated course grades. The self-concept subscales of mathematics and emotions were not significantly associated with expected grades.

H3 suggested there would be a negative relationship between student judgments of discrimination and academic success. Analysis using Spearman's rho testing was selected, as the scales for judgments of discrimination and student grades were not 
normally distributed. There was no statistically significant correlation in the data set between judgments of discrimination and the students' anticipated course grades $\left(\right.$ Spearman $\left.r_{s}(157)=-0.10, n=159, p=.23\right) . \mathrm{H} 3$ was not supported.

Table 1. Descriptive Statistics for Construct Scales

\begin{tabular}{lccc}
\hline & $N$ & $M$ & $S D$ \\
\hline Judgments of Teacher Expectations & 162 & 3.3 & 0.5 \\
Self-Concept (aggregate) & 159 & 3.6 & 0.4 \\
Mathematics & 159 & 2.5 & 1.2 \\
General Academic Skills & 159 & 3.8 & 0.7 \\
Verbal/Communication skills & 159 & 3.9 & 0.7 \\
Honesty/Reliability & 159 & 4.1 & 0.7 \\
Emotions & 159 & 2.8 & 0.8 \\
General Self-Concept & 159 & 4.0 & 0.6 \\
Judgments of Discrimination & 159 & 2.3 & 0.8 \\
\hline
\end{tabular}

Note: All scales were measured using a 1-5 Likert-type scale.

RQ1 asked if there was a difference between male and female students in their judgments of teacher expectations. The results of a two-tailed independent sample $t$-test indicate that there is no difference $(t(156)=-1.0, p=.32)$. Males $(n=60, M=3.2, S D=$ 0.5 ) and females $(n=96, M=3.3, S D=0.5)$ do not appear to differ in their judgments of teacher expectations. Similarly, RQ2 asked if there was a relationship between student race and those students' judgments of teacher expectations. The ANOVA of the race factor revealed no statistically significant difference, $F(5 / 152)=1.52, p=.19$ indicating 
that there is no difference in student judgments of teacher expectations based on the students' race $(n=159, M=3.3, S D=0.5)$, White/Caucasian $(n=91, M=3.3, S D=$ $0.48)$, African American $(n=11, M=3.0, S D=0.54)$, Hispanic $(n=16, M=3.4, S D=$ $0.49)$, Asian $(n=22, M=3.1, S D=0.44)$, Pacific Islander $(n=4, M=3.4, S D=.09)$, Other $(n=14, M=3.4, S D=0.50)$.

Table 2

Spearman Correlations

\begin{tabular}{lcccccccc}
\hline \multicolumn{1}{c}{ Variable } & 1 & 2 & 3 & 4 & 5 & 6 & 7 & 8 \\
\hline $\begin{array}{l}\text { 1. Judgments of Teacher } \\
\text { Expectations }\end{array}$ & - & & & & & & & \\
2. Self-Concept (aggregate) & $.24^{* *}$ & - & & & & & & \\
3. Mathematics & .02 & $.41^{* *}$ & - & & & & & \\
4. General Academic Skills & .15 & $.73^{* *}$ & $.24^{* *}$ & - & & & & \\
5. Communication skills & $.20^{*}$ & $.63^{* *}$ & -.01 & $.57^{* *}$ & - & & & \\
6. Honesty/Reliability & $.16^{*}$ & $.61^{* *}$ & .11 & $.32^{* *} .25^{* *}$ & - & & \\
7. Emotions & .04 & $.50^{* *}$ & .09 & $.18^{*}$ & .12 & $.25^{* *}$ & - & \\
8. General Self-Concept & $.29^{* *}$ & $.78^{* *}$ & $.19^{*}$ & $.62^{* *} .53^{* *}$ & $.37^{* *}$ & $.22^{* *}$ & - \\
9. Judgments of Discrimination & -.05 & $-.30^{* *}$ & -.02 & $-.17^{*}$ & -.11 & $-.32^{* *}$ & $-.27^{* *}$ & $-.22^{* *}$ \\
\hline
\end{tabular}

Note: $* p<.05 * * p<.01$ 


\section{Chapter 5 - Discussion}

The purpose of this study was to explore the relationship between student judgments of teacher expectations and academic success, the relationship between student self-concept and academic success, and the relationship between student judgments of discrimination and academic success. In addition, the questions of whether or not gender or race were associated with student judgments of teacher expectations were explored. The research explored attribution theory as a tool used by participants to account for their academic success.

H1 suggested that student judgments of teacher expectations would positively correlate with student academic success. The degree to which participants judged their professors' expectations was not positively associated with the students' anticipated course grade; therefore, $\mathrm{H} 1$ was not supported. While college-age students are the target population for examining teacher expectations and academic success, the scales used were designed for an elementary education population. Further, all of the available literature also targeted primary school-age children, which made applying similar research challenging. Considering the extensive literature supporting the argument that judgments of high teacher expectations result in higher academic outcomes (e.g., Agirdag et al., 2013; Harris \& Rosenthal, 1985; Jussim et al., 2005; Weinstein et al., 1982), this scale may not have been properly applied in this study. Participant comments indicated some confusion surrounding questions of teacher expectations. Two respondents commented that the scale inquiring about teacher expectations was challenging and open to interpretation. The students expressed a lack of personal relationship with their respective professors and limited opportunity to determine what their professors' beliefs 
were about them as students (e.g., levels of trust). There is scant literature that examines students' beliefs about college professors' expectations, which creates a challenge with attempting to dissect the study results related to $\mathrm{H} 1$. The results may be due to a different academic culture between primary school education and university education, where university students are not expecting to have a relationship with their professors, or they may simply not know what their professors expect of them. Considering the lack of scholarly research that examines college students' judgments of their professors' expectations, and the abundance of scholarly research that supports a relationship between teacher expectations and academic success for primary school students, this is a gap in research. Further studies may benefit college students and college professors alike.

$\mathrm{H} 2$ suggested that there would be a positive relationship between student scores on the self-concept scale and the students' academic success. Participants who reported high levels of self-concept also reported high anticipated course grades, which supported H2. These results also support the literature findings that students with higher levels of self-concept will experience higher academic success (Friedrich et al., 2015; Jussim, 1989; Madon \& Jussim, 1997; Marsh \& Martin, 2011; Weinstein \& Middlestadt, 1979). The assumptions of attribution theory suggest that behavior changes in an individual are motivated by the judgments and expectations of others, and some people may attribute their successes or failures to their own efforts or abilities (Jones \& Nisbett, 1972). Attribution theory may be a way to explain success or failure (Jaspars et al., 1983). The 
positive correlation between students' overall self-concept and anticipated course grades may be attributed to the students' self-concept and judgments of ability.

Self-concept subscales revealed mixed results. These are important because if self-concept as it relates to academic subspecialties (e.g., mathematics, verbal/communication) can be identified, students may be more likely to achieve academic success. The entire aggregated self-concept scale included all of the subscales (e.g., mathematics, verbal/communication skills), while the general academic subscale focused specifically on beliefs respondents hold about their overall academic abilities. There was a positive relationship between the general academic subscale and the students' expectations of course grades. Marsh and O’Neill (1984) argue that achievement in academic-specific areas is associated with self-concept in that same area. For example, the student with a high self-concept in mathematics will do well academically in mathematics. This is important because a good self-concept may mean that the students are more likely to be academically successful. Further, since selfconcept is in part formed by interpretations from a person's environment (Marsh \& Martin, 2011) and strongly through reflected appraisal (Bong \& Skaalvik, 2011) then teachers can potentially play a positive role in shaping academic self-concept and possibly academic success.

Low self-concept relating to mathematics did not significantly correlate with course grade expectations. The lack of statistical correlation may be linked to the field of communication studies as part of a liberal arts program. Self-concept relating to mathematical abilities could be discipline specific, where an engineering program would 
elicit higher mathematical self-concept, and a communication program would elicit lower mathematical self-concept as seen in these results. In contrast, participants who reported high self-concept relating to verbal/communication skills also reported high expected course grades. This could be attributed to the fact that participants in the study were recruited from communication courses, a field where they may feel more confident in their verbal/communication abilities.

Participants who reported high levels of self-concept with regard to honesty/reliability also reported high expectations for course grades. Marsh and Martin (2011) argue that levels of self-concept can help predict behavior; therefore, there may be a relationship between student judgments of honesty and their academic success. This is an important point because one could reasonably expect that honest/reliable students might be less likely to cheat and therefore put out more effort, which could result in higher grades.

The subscale pertaining to emotional stability found no significant correlation with course grade expectations. One explanation for this lack of statistical correlation could be that a person's emotional state (worrying excessively) would not make them any better or worse of a student and not impact their overall academic success. This is important when considering many college students may be juggling multiple demands in life in addition to their academic load. A college student experiencing high levels of personal stress may require compassion from their teacher but also confidence in their ability to get their work done. 
H3 suggested a negative correlation between students' beliefs that they have been recipients of discrimination and their academic success. This hypothesis was not supported. RQ2 asked if there was a relationship between students' race and their judgments of teacher expectations, and no relationship was found. These results may be a reflection of a college environment that is predominantly white with a small percentage of African American and Hispanic/Latino students participating in this study. The lack of statistical correlation may also simply be the students' abilities to take on the role of a student and focus on their academic goals. The majority of the responses relating to discrimination reported their discriminatory experiences to be associated with gender, a variable that was not specifically looked at within scholarly literature. Discriminatory experiences attributed to race were the second most common response followed by physical appearance.

RQ1 asked if there is any relationship between students' gender and their judgments of teacher expectations. While the literature supports different academic experiences between males and females (e.g., Bonnot \& Croizet, 2006; Chatard et al., 2006; Davies, Spencer, \& Steele, 2005; Eccles, Jacobs, \& Harold, 1990), this study did not find any difference between males and females and their judgments of teacher expectations. However, much of the literature's focus on gender related to mathematical abilities and gender stereotypes. Since this study drew from communication courses, it would seem reasonable that there would be no difference in judgments of teacher expectations between males and females. 


\section{Limitations and future research}

This study utilized convenience sampling from students in communication classes at a northwestern university. Results may differ across the nation and among different demographics to include socioeconomic status and a wider variety of academic majors, ages, and life experiences. Moreover, parts of a person's self-concept become more prominent with age (Marsh \& O'Neill, 1984), so focusing on college-age students with a study that incorporates self-concept, professor expectations, and academic outcome would help educators at the college level better understand how their expectations might impact student success.

The scale that attempted to measure student judgments of teacher expectations may not have been the most appropriate for a college population. Future research should include a new scale that focuses on college students and their judgments of professor expectations, which would be a valuable pedagogical tool for assessing college academic success. Additionally, research should include exploring what expectations university students hold for their professors.

Considering the literature that supports the notion that disadvantaged students (e.g., students of color, older students, females, new students) are more susceptible to expectations resulting in a behavioral shift and fulfillment of those expectations (Agirdag et al., 2013; Jussim \& Harber, 2005; Madon \& Jussim, 1997; Sorhagen, 2013), future research should also examine disadvantaged students who are in college to include students that are among low socioeconomic status; students with low academic success; students who are in recovery programs; students who hold veteran status; students who 
are single parents; students of color; students within the lesbian, gay, bisexual, transgender, queer (LGBTQ) community; and students who are on parole after a prison sentence. Jussim and Harber (2005) argue that these are the types of students who are most susceptible to expectations, yet very little research exists that examines students and these circumstances.

The survey in this study only took into account judgments from the students' point of view. A more accurate view of teacher expectations that could manifest into expectancy effects would also include teacher accounts of their expectations (Agirdag et al., 2013; Friedrich et al., 2015; Madon \& Jussim, 1997). This study can only make suggestions relating to expectancy effects.

Finally, the sample size of this study resulted in a reduced degree of power than would be desirable, where an additional 25 participants would have provided satisfactory power. However, this study was sufficiently powered to find statistical significance for meaningful correlations including the subtle but statistically significant correlation between the self-concept subscale of honesty/reliability and anticipated course grade.

\section{Conclusion}

The privilege of being an educator is accompanied by great responsibility. Teachers have the opportunity to facilitate student success, as noted by Jaime Escalante's expectations of his students in Stand and Deliver. If expectancy effects can be harnessed and used in the classroom, understanding the dynamics associated with teacher expectations and academic outcomes could be a valuable pedagogical tool in manifesting student success. Extending this study deeper would contribute to the fields of 
Communication, Psychology, and Education and potentially increase academic success rates. Students with a high level of self-concept may find their way to academic success, as supported with this study. However, students, particularly disadvantaged students, with low self-concept are at greater risk for academic failure.

Considering that reflected appraisal is the most dominant source of information molding one's self-concept (Bong \& Skaalvik, 2003), educators are in a position to reflect positive information back to students and favorably enhance self-concept. If students with a low self-concept were to receive positive expectations for success from their teachers and positive reflected appraisal, the literature suggests that the student behaviors may shift prompting fulfillment of the expectations and ultimately greater academic success. If more teachers such as Escalante made a clear declaration of their belief in their students' abilities, those students may work harder, take more risks (e.g., take harder classes, seek out tutoring, join a supportive student organization), see the positive outcomes of their efforts in the form of grades, and their self-concept and success rates may improve. Teaching is an honor with no greater reward than to see one's students succeed. 


\section{References}

Agirdag, O., Van Avermaet, P., Van Houtte, M. (2013). School segregation and math achievement: A mixed-method study on the role of self-fulfilling prophecies. Teachers College Record, 115(3), 1-50.

Alfaro, E. C., Umaña-Taylor, A. J., Gonzales-Backen, M. A., Bámaca, M. Y., \& Zeiders, K. H. (2009). Latino adolescents' academic success: The role of discrimination, academic motivation, and gender. Journal of Adolescence, 32(4), 941-962. doi:10.1016/j.adolescence.2008.08.007

Baysu, G., Celeste, L., Brown, R., Verschueren, K., \& Phalet, K. (2016). Minority adolescents in ethnically diverse schools: Perceptions of equal treatment buffer threat effects. Child Development, 87(5), 1352-1366. doi:10.1111/cdev.12609

Bong, M., \& Skaalvik, E. M. (2003). Academic self-concept and self-efficacy: How different are they really? Educational Psychology Review, 15(1), 1-40. doi:10/1023/A:102130240

Bonnot, V. \& Croizet, J.C. (2006). Stereotype internalization and women's math performance: The role of interference in working memory. Journal of Experimental Social Psychology, 43(6), 857-866. doi:10.1016/j.jesp.2006.10.006

Brophy, J. E. (1983). Research on the self-fulfilling prophecy and teacher expectations. Journal of Educational Psychology, 75(5), 631-661. doi:10.1037/00220663.75.5.631

Chaffee, S. H. (1991). Explication. Newbury Park, CA: SAGE Publications, Inc. Chatard, A., Guimond, S., \& Selimbegovic, L. (2006). "How good are you in math?” The 
effect of gender stereotypes on students' recollection of their school marks. Journal of Social Psychology, 43(6), 1017-1024. doi:10.1016/j.jesp.2006.10.024

Coleman, C. L. (1993). The influence of mass media and interpersonal communication on societal and personal risk judgments. Communication Research, 20(4), 611-628.

Cooper, H., \& Hazelrigg, P. (1988). Personality moderators of interpersonal expectancy effects: An integrative research review. Journal of Personality and Social Psychology, 55(6), 937-949.

Davies, P. G., Spencer, S. J., \& Steele, C. M. (2005). Clearing the air: Identity safety moderates the effects of stereotype threat on women's leadership aspirations. Journal of Personality and Social Psychology, 88(2), 276-287. doi:10.1037/0022351488.2 .276

Davis-Kean, P. E. (2005). The influence of parent education and family income on child achievement: The indirect role of parental expectations and the home environment. Journal of Family Psychology, 19(2), 294-304. doi:10.1037/08933200.19.2.294

Ditzfeld, C. P., \& Showers, C. J. (2013). Self-structure: The social and emotional contexts of self-esteem. In V. Ziegler-Hill (Ed.), Self-Esteem, (pp. 21-42). New York, NY: Psychology Press.

Eccles, J. S., Jacobs, J. E., \& Harold, R. D. (1990). Gender role stereotypes, expectancy effects, and parents' socialization of gender differences. Journal of Social Issues, 46(2), 183-201. doi:10/1111/j.1540-4560.1990.tb01929.x

Eccles, J. S., Wong, C. A., \& Peck, S. C. (2006). Ethnicity as a social context for the 
development of African-American adolescents. Journal of School Psychology, 44(5), 407-426. doi:10.1016/j.jsp.2006.04.001

Eden, D. (1990). Pygmalion in management: Productivity as a self-fulfilling prophecy. Lexington, MA: Lexington Books.

Firestone, C., \& Scholl, B. J. (2015). When do ratings implicate perception versus judgment? The "overgeneralization test" for top-down effects. Visual Cognition, 23(9-10), 1217-1226. doi:10.1080/13506285.2016.1160171

Fischbach, A., Baudson, T. G., Preckel, F., Martin, R., \& Brunner, M. (2013). Do teacher judgments of student intelligence predict life outcomes? Learning and Individual Differences, 27, 109-119. doi:10.1016/j.lindif.2013.07.004

Friedrich, A., Flunger, B., Nagengast, B., \& Jonkmann, K., Trautwein, U. (2015). Pygmalion effects in the classroom: Teacher expectancy effects on students' math achievement. Contemporary Educational Psychology, 41, 1-12. doi:10.1016/j.cedpsych.2014.10.006

Funder, D. C., \& Colvin, R. C. (1988). Friends and strangers: Acquaintanceship, agreement, and the accuracy of personality judgment. Journal of Personality and Social Psychology, 55(1), 149-158. doi:10.1037/0022-3514.55.1.149

Garner, W. R., Hake, H. W., \& Eriksen, C. W. (1956). Operationism and the concept of perception. Psychological Review, 63(3), 149-159.

Good, C., Aronson, J., \& Harder, J. A. (2007). Problems in the pipeline: Stereotype threat and women's achievement in high-level math courses. Journal of Applied Developmental Psychology, 29(1), 17-28. doi:10.1016/j.appdev.2007.10.004 
Gurland, S. T., \& Evangelista, J. E. (2014). Teacher-student relationship quality as a function of children's expectancies. Journal of Social and Personal Relationships, 32(7), 879-904. doi:10/1177/0265407514554511

Haimerl, C. \& Fries, S. (2010). Self-fulfilling prophecies in media-based learning: Content relevance moderates quality expectation effects on academic achievement. Learning and Instruction, 20(6), 498-510. doi:10/1016/j.learninstruc.2009.07.002

Harris, M. J., \& Rosenthal, R. (1985). Mediation of interpersonal expectancy effects: 31 meta-analyses. Psychological Bulletin, 97(3), 363-386.

Huang, C. (2011). Self-concept and academic achievement: A meta-analysis of longitudinal relations. Journal of School Psychology, 49(5), 505-528. doi:10.1016/j.js0/2011.07.001

Hughes, A., Galbraith, D., \& White, D. (2011). Perceived competence: A common core for self-efficacy and self-concept? Journal of Personality Assessment, 93(3), 278289. doi:10.1080/00223891.2011.559390

Jaspars, J., Fincham, F. D., \& Hewstone, M. (1983). Attribution theory and research: Conceptual, developmental and social dimensions. New York: NY: Academic Press.

Jones, E. E., \& Nisbett, R. E. (1972). The actor and the observer: Divergent perceptions of the causes of behavior. In E. E. Jones, D. E. Kanouse, H. H. Kelly, R. Nisbett, S. Valines, \& B. Weiner (Eds.), Attribution: Perceiving the causes of behavior (pp. 79-04). Hillsdale, NJ: Lawrence Erlbaum Associations, Inc. 
Jussim, L. (1989). Teacher expectations: Self-fulfilling prophecies, perceptual biases, and accuracy. Journal of Personality and Social Psychology, 57(3), 469-480.

Jussim, L., \& Eccles, J. S. (1992). Teacher expectations II: Construction and reflection of student achievement. Journal of Personality and Social Psychology, 63(6), 947961.

Jussim, L., \& Eccles, J. (1995). Social development. In N. Eisenberg (Ed.), Naturally occurring interpersonal expectancies (pp. 74-108). Thousand Oaks, CA: Sage.

Jussim, L., \& Harber, K. D. (2005). Teacher expectations and self-fulfilling prophecies: Knowns and unknowns, resolved and unresolved controversies. Personality and Social Psychology Review, 9(2), 131-155.

Jussim, L., Harber, K. D., \& Crawford, J. T. (2005). Social reality makes the social mind: Self-fulfilling prophecy, stereotypes, bias, and accuracy. Interaction Studies, 6(1), 85-102.

Karcher, M. J., Davidson, A. J., Rhodes, J. E., \& Herrera, C. (2010). Pygmalion in the program: The role of teenage peer mentors' attitude in shaping their mentees' outcomes. Applied Developmental Science, 14(4), 212-227.

doi:10.1080/10888691.2010.516188

Kiefer, A. K., \& Sekaquaptewa. (2007). Implicit stereotypes and women's math performance: How implicit gender-math stereotypes influence women's susceptibility to stereotype threat. Journal of Experimental Psychology, 43(5), 825-832. doi:10.1016/j.jesp.2006.08.004

Kierein, N. M., \& Gold, M. A. (2000). Pygmalion in work organizations: A meta- 
analysis. Journal of Organizational Behavior, 21(8), 913-928.

doi:10.1002/1099-1379(200012)21:8<913::AID-JOB62>3.0CO2-\#

Madon, S., \& Jussim, L. (1997). In search of the powerful self-fulfilling prophecy. Journal of Personality and Social Psychology, 74(4), 791-809.

Marsh, H. W., \& Martin, A. J. (2011). Academic self-concept and academic achievement: Relations and causal ordering. British Journal of Educational Psychology, 81(1), 59-77. doi:10.1348/000709910x503501

Marsh, H. W., \& O’Neill, R. (1984). Self description questionnaire III: The construct of validity of multidimensional self-concept ratings by late adolescent. Journal of Educational Measurement, 21(2), 153-174.

Mathews, J. (2010, March 31). Jaime Escalante dies, inspired 1988 film 'Stand and Deliver.' The Washington Post. Retrieved from http://www.washingtonpost.com/ wp-dyn/content/article/2010/03/30/AR2010033003629.html

McKown, C., \& Weinstein, R. S. (2002). Modeling the role of child ethnicity and gender in children's differential response to teacher expectations 1. Journal of Applied Psychology, 32(1), 159-184. doi:10.1111/j.1559-1816.2002.tb01425.x

Musca, T (Producer), \& Menéndez, R (Director). (1988). Stand and deliver [Motion picture]. United States: Warner Bros.

Pipitone, C. J., \& Welch-Cline, R. J. (1989). Subtle opportunities: The self-fulfilling prophecy, gender, and self-esteem. The Florida Communication Journal, 17(1), $15-22$.

Robinson, J. A. (2017). Exploring attribution theory and bias. Communication Teacher, 
31(4), 209-213. doi:10.1080/17404622.2017.1358387

Rosenberg, M. (1965). Society and the adolescent self-image. Princeton, NY: Princeton University Press.

Rosenthal, R., \& Jacobson, L. (1968). Pygmalion in the classroom. New York, NY: Holt, Rinehart, and Winston.

Rosenthal, R., \& Rubin, D. R. (1978). Interpersonal expectancy effects: The first 345 studies. The Behavioral and Brain Sciences, 3, 377-386.

Rubie-Davies, C. M., Peterson, E. R., Sibley, C. G., \& Rosenthal, R. (2015). A teacher expectation intervention: Modelling the practices of high expectation teachers. Contemporary Educational Psychology, 40, p. 72-85. doi:10.1016/j.cedpsych.2014.03.003

Sorhagen, N. S. (2013). Early teacher expectations disproportionately affect poor children's high school performance. Journal of Educational Psychology, 105(2), 465-477. doi:10.1037/a0031754

Spencer, S. J., Steele C. M., \& Quinn, D. M. (1999). Stereotype threat and women's math performance. Journal of Experimental Social Psychology, 35(1), 4-28. doi:10/1006/jesp.1998.1373

Steele, J. R., \& Ambady, N. (2005). "Math is hard!” The effect of gender priming on women's attitudes. Journal of Experimental Social Psychology, 42(4), 428-436. doi:10.1016/j.jesp.2005.06.003

Thompson, A. R., \& Gregory, A. (2011). Examining the influence of perceived discrimination during African American adolescents' early years of high school. 
Education and Urban Society, 43(1), 3-25. doi:10.1177/0013124510379827

Tversky, A. \& Kahneman, D. (1974). Judgment under uncertainty: Heuristics and biases. Science, 185(4157), 1124-1131.

Weiner, B., Frieze, I., Kukla, A., Reed, L., Rest, S., \& Rosenbaum, R. M. (1972). Perceiving the causes of success and failure. In E. E. Jones, D. E. Kanouse, H. H. Kelly, R. Nisbett, S. Valines, \& B. Weiner (Eds.), Attribution: Perceiving the causes of behavior (pp. 95-120). Hillsdale, NJ: Lawrence Erlbaum Associations, Inc.

Weinstein, R. S., Marshall, H. H., Brattesani, K. A., \& Middlestadt, S. E. (1982). Student perceptions of differential teacher treatment in open and traditional classrooms. Journal of Educational Psychology, 74(5), 678-692.

Weinstein, R. S., \& Middlestadt, S. E. (1979). Student perceptions of teacher interactions with male high and lower achievers. Journal of Educational Psychology, 74(4), 421-431.

Williams, D. R., Yu, Y., Jackson, J. S., \& Anderson, N. B. (1997). Racial differences in physical and mental health. Journal of Healthy Psychology, 2(3), 335-351. doi:10.1177/135910539700200305

Wylie, R. C. (1974). The self-concept. Lincoln, NE: University of Nebraska Press. Zeigler-Hill, V. (2013). The importance of self-esteem. In V. Ziegler-Hill (Ed.), SelfEsteem, (pp. 1-20). New York, NY: Psychology Press. 
Appendix

\section{Consent Informed Consent Form (Thesis)}

You are invited to participate in a research study conducted by Jennifer Campbell under the direction of Dr. Frank. This study attempts to collect information about perceptions of professor expectations. You were selected as a possible participant in this study because you are enrolled as an undergraduate in a communication course. If your professor is offering extra credit for your participation, please complete this survey at a computer with internet access and a printer.

\section{Procedures}

If you decide to participate, you will be asked to complete the following questionnaire. The questionnaire will take approximately 20 minutes or less.

\section{Risks/Discomforts}

Risks are minimal for involvement in this study. However, you may feel uncomfortable when asked to share information about your perceptions of discrimination. You are welcome to skip any question that you feel uncomfortable answering.

\section{Benefits}

You may not receive any direct benefit from taking part in this study. However, it is hoped that through your participation, the study may help to increase knowledge which may help others in the future.

\section{Confidentiality}

All information that is obtained in connection with this study will be kept confidential and will only be reported in an aggregate format (by reporting only combined results and never reporting individual ones). All questionnaires will be concealed, and no one other than the research team will have access to them. At no point will you name be linked to your answers.

\section{Compensation}

You may earn academic extra credit for your participation. Follow the directions at the end of the survey to print and turn your survey completion form in to the pink drop box in the Communication Department offices, UCB 440. Your form will not be linked to your survey responses. Your name is collected only so that your professor may give you extra credit for your class project. 


\section{Participation}

Participation in this research study is completely voluntary. You have the right to withdraw at any time or refuse to participate entirely, and it will not affect your course grade in the class or standing with the university. If you wish to receive extra credit but do not wish to complete the survey, contact the researcher for an alternative extra credit opportunity.

\section{Questions about the Research}

If you have questions or concerns regarding this study, contact Jennifer Campbell at jlc7@pdx.edu or Dr. Frank at 1frank@pdx.edu.

\section{Questions about your Rights as Research Participants}

If you have questions or concerns about your rights as a research subject, please contact the PSU Office of Research Integrity, Market Center Building 6th floor, Portland State University, 503-725-2227. By completing this survey, you are certifying that you are 18 years of age or older, that you have read and understand the above information and agree to take part in the survey. Press the "Print" button below to keep a copy of this form for your own records. If at this point you choose to continue in this research study, please click ">>" to continue. 
percep Below is a list of statements dealing with how a professor might treat you. In this scenario, consider your current communication professor whose class you are in this quarter when answering each question. If you are in more than one communication class, please choose the one that you attended most recently. Please rate each of the following questions, where $1=$ never and 5 = always.

\begin{tabular}{|c|c|c|c|c|c|}
\hline & $\begin{array}{c}\text { Never } \\
1(1)\end{array}$ & $\begin{array}{l}\text { Rarely } \\
2(2)\end{array}$ & $\begin{array}{c}\text { Sometimes } \\
3(3)\end{array}$ & $\begin{array}{l}\text { Often } \\
4(4)\end{array}$ & $\begin{array}{c}\text { Always } \\
5(5)\end{array}$ \\
\hline $\begin{array}{c}\text { The } \\
\text { professor } \\
\text { makes me } \\
\text { feel I did } \\
\text { very well } \\
\text { when I give } \\
\text { the right } \\
\text { answer (1) }\end{array}$ & & & & & \\
\hline $\begin{array}{l}\text { The } \\
\text { professor } \\
\text { spends time } \\
\text { working } \\
\text { with me (2) }\end{array}$ & & & & & \\
\hline $\begin{array}{c}\text { The } \\
\text { professor } \\
\text { asks me easy } \\
\text { questions (3) }\end{array}$ & & & & & \\
\hline $\begin{array}{c}\text { The } \\
\text { professor is } \\
\text { excited } \\
\text { when } \\
\text { working } \\
\text { with me (4) }\end{array}$ & & & & & \\
\hline $\begin{array}{l}\text { I am given } \\
\text { special } \\
\text { privileges } \\
(5)\end{array}$ & & & & & \\
\hline $\begin{array}{l}\text { The } \\
\text { professor } \\
\text { makes me } \\
\text { feel bad } \\
\text { when I do }\end{array}$ & & & & & \\
\hline
\end{tabular}


not have the right answer

The professor scolds me for not trying (7)

The professor scolds me for not listening (8)

The professor makes me feel that I have not done my work well

(9)

The professor asks me if I understand the work

When I give the wrong answer, the professor tells me how I can make my answer better (11)

The professor asks other students to help me (12) 


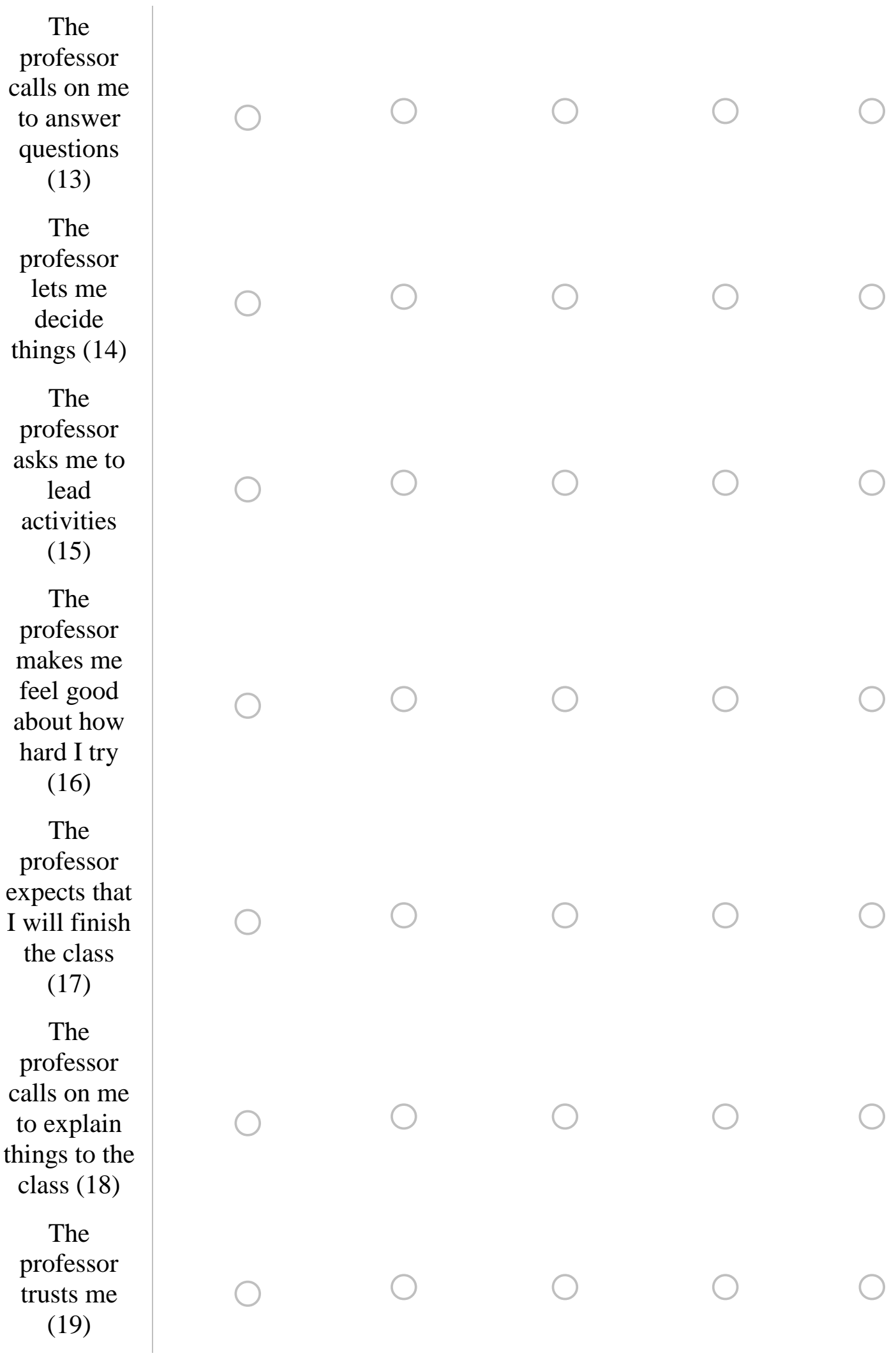


The
professor is
interested in
me (20)

syllabus In this current communication class, I am learning what the syllabus says I should be learning.

Strongly disagree 1 (1)

Disagree 2 (2)

Neither disagree nor agree 3

Agree 4 (4)

Strongly agree 5

learning I am learning something in this current communication course.

Strongly disagree 1

Disagree 2 (2)

Neither agree nor disagree 3 (3)

Agree 4 (4)

Strongly agree 5

grade What grade do you expect to receive in this current communication course? 
gpa What is your approximate overall college grade-point average (GPA)?

$\boldsymbol{\nabla} 4.0(1) \ldots 0$ to $0.2(13)$

selfcon Below is a list of statements dealing with your general feelings about yourself. Please rate each of the following statements, where $1=$ strongly disagree and 5 $=$ strongly agree.

$\begin{array}{cccc}\text { Strongly } & \text { Disagree } & \begin{array}{c}\text { Neither } \\ \text { agree nor }\end{array} & \text { Agree } \\ \text { disagree } & 2 & \text { disagree } & 4 \\ 1 & (6) & 3 & (4) \\ (1) & & (8) & \end{array}$

Strongly agree 5

(2)

I find
mathematics is
one of my best
subjects. (1)
Overall, I have
a lot to be
proud of. (2)
I am honest. (3)
I am hopeless
in
communication
classes. (4)
I worry more
than I need to.
$\quad$ (5)
I get bad grades
in most school
subjects. (6)
I get good
grades in
mathematics.
(7)


Most things I do, I do well.

(8)

I often tell lies. (9)

Work in
communication
classes is easy
for me. (10)
I am a nervous
person. (11)
I learn things
quickly in most
school subjects.

I have always done well in mathematics.

(13)

Overall, most things I do turn out well. (14)

I sometimes cheat. (15)

Communication is one of my best subjects. (16)

I often feel confused and mixed up. (17)

I do things as well as most people. (18)

I get good grades in communication. 
(19)

I get upset easily. (20)

I am good at most school subjects. (21)

If I really try, I can do almost anything I want to do. (22)

I sometimes take things that belong to other people. (23)

I learn things quickly in communication classes. (24)

I worry about a lot of things.

Overall, I am a failure. (26)

I sometimes tell lies to stay out of trouble. (27)

discrim In the last 10 years, have you experienced any of these situations (where $1=$ very untrue of me and 5 = very true of me)?

$\begin{array}{ccccr}\begin{array}{c}\text { Very untrue } \\ \text { of me }\end{array} & \begin{array}{c}\text { Untrue of } \\ \text { me }\end{array} & \text { Neutral } & \text { True of me } & \begin{array}{c}\text { Very true } \\ \text { of me }\end{array} \\ 1(1) & 2(5) & 3(4) & 4(7) & 5(9)\end{array}$

You are treated with less courtesy than other 
people are.

(1)

You are

treated with less respect than other people are.

You receive poorer treatment than other people at restaurants and stores.

People act as if you are not smart. (5)

People act as if they are afraid of you. (6)

People act as if they think you are dishonest.

(8)

People act as if they are better than you are. (9)

You are called names or insulted.

(10)

You are threatened or harassed. 
(11)

Display This Question:

If In the last 10 years, have you experienced any of these situations (where $1=$ very untrue of me a... [ True of me4] (Count) > = 1

Or In the last 10 years, have you experienced any of these situations (where $1=$ very untrue of me a... [ Very true of me 5] (Count) > = 1

discrim 2 What do you think is the main reason for these experiences? Check all that apply.

Your ancestry or origin (1)

Your gender (2)

Your race (3)

Your religion (4)

Your height (5)

Your weight (6)

Some other aspect of your physical appearance (7)

Your sexual orientation (8)

Your education or income level (9)

A physical disability (10)

Other (please specify) (11) 
firstgen Are you a first-generation college student (the first person in your immediate family to attend college)?

Yes (1)

No (0)

firstq Is this your very first quarter attending college?

Yes (1)

No (0)

age What year were you born?

$\boldsymbol{\nabla} 2000(1) \ldots 1900(101)$

gender What is your gender?

Male (1)

Female (2)

Other (3)

race What is your race?

$\boldsymbol{\nabla}$ White/Caucasian (1) ... Other (7) 
misc Is there anything else you would like to share with us about the survey topic? 